\title{
Gambaran Bullying dan Hubungannya dengan Masalah Emosi dan Perilaku pada Anak Sekolah Dasar
}

\author{
Soedjatmiko, ${ }^{*}$ Waldi Nurhamzah, ${ }^{*}$ Anastasia Maureen, ${ }^{*}$ Tjhin Wiguna, ${ }^{* *}$ \\ ${ }^{*}$ Departemen Ilmu Kesehatan Anak, ${ }^{* *}$ Departemen Psikiatri, Fakultas Kedokteran Universitas Indonesia \\ RS. Dr. Cipto Mangunkusumo, Jakarta
}

Latar belakang. Prevalensi bullying pada anak SD di Indonesia belum diketahui.

Tujuan. Mengetahui gambaran dan prevalensi bullying, pemahaman pelajar mengenai istilah bullying, hubungan antara status bullying dengan masalah emosi, dan perilaku serta prestasi akademis.

Metode. Penelitian potong lintang dengan subyek pelajar SD kelas V usia 9-11 tahun di SDN Cikini 02 Pagi dan SDS Tunas Bangsa pada bulan Oktober 2011. Bullying dinilai menggunakan Olweus Bully/Victim Questionnaire yang dimodifikasi, sedangkan masalah emosi dan perilaku dideteksi menggunakan self-report Strengths and Difficulties Questionnaire (SDQ). Prestasi akademis dinilai berdasarkan nilai rapor tengah semester.

Hasil. Penelitian dilakukan pada 76 subyek dan didapatkan prevalensi bullying 89,5\%. Tidak terdapat perbedaan jenis kelamin pada subyek yang terlibat dalam bullying. Sebagian besar subyek yang terlibat bullying berusia $>9$ tahun. Subyek dengan status sosio-ekonomi rendah cenderung menjadi korban, sedangkan subyek dengan status sosio-ekonomi menengah dan tinggi cenderung menjadi korban sekaligus pelaku. Tipe bullying tersering adalah fisik. Pelaku bullying terbanyak adalah teman sebaya. Bullying paling sering terjadi di ruang kelas pada waktu istirahat sekolah. Dampak bullying jangka pendek tersering yang dialami korban adalah perasaan sedih. Sebagian besar korban melaporkan bullying yang dialaminya kepada orang lain. Hanya $22 \%$ subyek yang mengetahui istilah bullying dengan tepat. Tidak didapatkan hubungan antara status bullying dengan masalah emosi dan perilaku maupun prestasi akademis.

Kesimpulan. Prevalensi bullying pada murid kelas V SDN Cikini 02 Pagi dan SDS Tunas Bangsa 89,5\%. Pemahaman tentang istilah bullying pada anak SD di Jakarta Pusat rendah. Tidak didapatkan hubungan antara status bullying dengan masalah emosi dan perilaku maupun prestasi akademis.

Sari Pediatri 2013;15(3):174-80.

Kata kunci: bullying, sekolah dasar, masalah emosi dan perilaku, prestasi akademis

Alamat korespondensi:

Dr. Anastasia Maureen, Sp.A, Kompleks Banjarwijaya Cluster Cemara I, Blok B 3/30 Cipondoh-Tangerang. Hp: 021-71141167.

E-mail: anastasia_maureen@yahoo.com

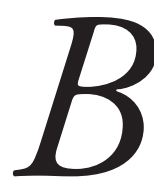

ullying adalah penyalahgunaan kekuatan yang disengaja dan berulang-ulang oleh seorang anak atau lebih terhadap anak lain, dengan maksud untuk menyakiti atau menimbulkan 
perasaan tertekan/stres. ${ }^{1,2}$ Bullying merupakan istilah yang asing bagi kebanyakan masyarakat Indonesia, walaupun fenomena ini telah berlangsung lama dan terjadi di berbagai segi kehidupan termasuk dunia pendidikan. Belum ada penelitian formal yang mengukur pemahaman murid terhadap istilah bullying di Indonesia.

Bullying merupakan fenomena yang tersebar di seluruh dunia. Prevalensi bullying diperkirakan 8 hingga 50\% di beberapa negara Asia, Amerika, dan Eropa..$^{3-7}$ Belum terdapat data mengenai prevalensi bullying di Indonesia. Penelitian $\mathrm{Amy}^{8}$ pada tahun 2006, diperkirakan 10\%-16\% pelajar Sekolah Dasar (SD) kelas IV-VI di Indonesia mengalami bullying sebanyak satu kali per minggu. Bullying pada anak paling sering terjadi di sekolah, tetapi belum banyak guru di Indonesia yang menganggap bullying sebagai masalah serius. ${ }^{9}$ Survei di berbagai belahan dunia menyatakan bahwa bullying paling banyak terjadi pada usia 7 tahun (kelas II SD), dan selanjutnya menurun hingga usia 15 tahun. ${ }^{1}$ Studi lain menyatakan prevalensi bullying tertinggi pada usia 7 tahun dan 10-12 tahun. ${ }^{10}$ Anak laki-laki lebih sering terlibat dalam bullying dibandingkan anak perempuan. ${ }^{1,6,11}$

Bullying memberikan dampak negatif terhadap pelaku dan korban. Dampak terbesar dialami oleh korban bullying. Korban bullying mengalami gangguan psikosomatik dan psikososial. Gangguan prestasi belajar dan tindakan bolos sekolah yang kronik juga dikaitkan dengan kemungkinan menjadi korban bullying. ${ }^{1}$ Strategi dalam penanganan bullying memerlukan pendekatan holistik yang melibatkan guru, orangtua, murid, pekerja sosial, dan dokter. ${ }^{11,12}$ Dokter anak memiliki peran penting dalam permasalahan bullying. Peran dokter anak di antaranya mengidentifikasi pasien berisiko, menasihati keluarga, dan mendukung implementasi program anti-bullying di sekolah. ${ }^{11,13}$ Peran lainnya ialah melakukan skrining masalah mental dan melakukan rujukan apabila perlu. ${ }^{1,14}$

Tujuan penelitian ini adalah untuk mengetahui gambaran bullying, pemahaman pelajar terhadap istilah bullying, dan hubungan antara perilaku ini dengan masalah emosi dan perilaku serta prestasi akademis pada anak SD di Jakarta.

\section{Metode}

Desain penelitian potong lintang dengan subyek seluruh anak kelas V SDN Cikini 02 Pagi dan SDS Tunas Bangsa di Jakarta Pusat. Penelitian berlangsung pada bulan Oktober 2011. Pemilihan subyek dari kedua sekolah tersebut dilakukan dengan alur sebagai berikut, sekolahsekolah dasar yang terdaftar di wilayah Jakarta Pusat berjumlah 410 sekolah, terdiri dari 2 kelompok, yaitu negeri (286 SD) dan swasta (124 SD). Pada masingmasing kelompok dilakukan simple random sampling untuk memilih 1 SD per kelompok dengan cara diundi. Jumlah total murid kelas $\mathrm{V}$ usia 10-12 tahun yang terdaftar di kedua sekolah tersebut adalah 78 orang dan seluruhnya diikutsertakan dalam penelitian.

\section{Tahap pra penelitian}

Kuesioner yang digunakan untuk mengukur perilaku bullying disusun sendiri oleh peneliti dengan memodifikasi Olweus Bully/Victim Questionnaire, ${ }^{15}$ yaitu kuesioner bullying yang digunakan secara luas di dunia dan memiliki validitas dan reliabilitas yang baik. Analisis psikometri kuesioner bullying yang disusun adalah penilaian content validity dan reliabilitas. Uji instrumen dilakukan terhadap 30 siswa kelas V di SDS At-Taqwa Jakarta Pusat dan menghasilkan reliabilitas yang baik (Cronbach's $\alpha$ 0,86 untuk subskala korban dan Cronbach's $\alpha$ 0,78 untuk subskala pelaku). Uji bahasa dilakukan terhadap 10/30 siswa untuk menilai pemahaman mereka terhadap pertanyaan-pertanyaan kuesioner tersebut. Beberapa kata yang sulit dimengerti oleh siswa telah diganti dan beberapa pertanyaan terbuka dihapuskan.

\section{Prosedur penelitian}

Setelah lolos kaji etik, peneliti mengajukan permohonan ijin kepada kepala sekolah SD yang terpilih untuk melakukan penelitian. Orangtua atau wali sah membuat informed consent secara tertulis dan mengisi kuesioner untuk orang tua. Kuesioner untuk orang tua berisi pertanyaan-pertanyaan demografi seperti suku bangsa, jumlah tanggungan, dan jumlah pendapatan total keluarga.

Subyek penelitian diberikan kuesioner untuk diisi sendiri (self-administered questionnaire), dan didampingi oleh peneliti dan asisten peneliti. Pengisian kuesioner terdiri dari 2 tahap, yaitu pengisian SDQ (Tahap I) dan kuesioner bullying (Tahap II). Keduanya dilakukan di ruang kelas, pada hari yang sama, dan dikondisikan seperti sedang menghadapi ujian tertulis. Waktu yang disediakan untuk pengisian SDQ dan kuesioner 
bullying masing-masing 15 dan 45 menit. Kuesioner yang telah diisi diperiksa ulang dan bila belum lengkap dikembalikan kepada responden untuk dilengkapi.

Analisis statisitik dilakukan dengan program SPSS versi 17.0. Korelasi variabel bebas dan tergantung dianalisis dengan uji chi-square, Fisher exact, Kolmogorov-Smirnov, uji T tidak berpasangan, dan one-way Anova. Nilai p dianggap bermakna secara statistik jika $<0,05$.

\section{Hasil}

Subyek penelitian berjumlah 78 orang. Dua orang subyek dari SDN Cikini 02 Pagi tidak masuk pada saat penelitian sehingga dieksklusi. Jumlah subyek berjenis kelamin laki-laki sebanding dengan perempuan. Sebagian besar subyek $(78,9 \%)$ berusia 10 tahun (rentang 9-11 tahun). Lebih dari separuh jumlah subyek memiliki status sosio-ekonomi menengah, dan hanya 1 subyek dengan status sosio-ekonomi tinggi (Tabel 1).

Selama 2 bulan terakhir, 89,5\% subyek pernah terlibat dalam perilaku-perilaku yang dapat dikategorikan sebagai bullying, baik sebagai korban maupun pelaku. Klasifikasi status bullying tertera pada Tabel 2. Korban bullying 85,6\% siswa (korban dan korban sekaligus pelaku) setidaknya 2-3 kali dalam sebulan. Gambaran bullying yang dialami korban tertera pada Tabel 3.

Tabel 1. Karakteristik sosiodemografi subyek penelitian

\begin{tabular}{lcc}
\hline & $\begin{array}{c}\text { Frekuensi } \\
(\mathrm{n}=76)\end{array}$ & $\%$ \\
\hline Asal sekolah & & \\
$\quad$ SDN Cikini 02 Pagi & 35 & 46,1 \\
$\quad$ SDS Tunas Bangsa & 41 & 53,9 \\
Jenis kelamin & & \\
$\quad$ Laki-laki & 37 & 48,7 \\
$\quad$ Perempuan & 39 & 51,3 \\
Usia (tahun) & & \\
9 & 10 & 13,2 \\
10 & 60 & 78,9 \\
$\quad 11$ & 6 & 7,9 \\
Status sosio-ekonomi & & \\
$\quad$ Rendah & 32 & 42,1 \\
$\quad$ Menengah ke bawah & 25 & 32,9 \\
$\quad$ Menengah ke atas & 11 & 14,5 \\
$\quad$ Tinggi & 1 & 1,3 \\
$\quad$ Tidak menjawab & 7 & 9,2 \\
\hline
\end{tabular}

Tabel 2. Status bullying

\begin{tabular}{lcc}
\hline Status & Frekuensi $(\mathrm{n}=76)$ & $\%$ \\
\hline Korban & 30 & 39,5 \\
Pelaku & 3 & 3,9 \\
Korban sekaligus pelaku & 35 & 46,1 \\
Tidak terlibat & 8 & 10,5 \\
\hline
\end{tabular}

Tabel 3. Gambaran perilaku bullying menurut korban dan korban sekaligus pelaku

\begin{tabular}{|c|c|c|}
\hline & $\begin{array}{l}\text { Frekuensi } \\
(\mathrm{n}=65)\end{array}$ & $\%$ \\
\hline \multicolumn{3}{|l|}{ Tipe bullying } \\
\hline Fisik & 61 & 93,8 \\
\hline Verbal & 59 & 90,8 \\
\hline Psikologis dan emosional & 54 & 83,1 \\
\hline Cyberbullying & 17 & 26,2 \\
\hline $\begin{array}{l}\text { Pengambilan/perusakan barang } \\
\text { milik pribadi }\end{array}$ & 41 & 63,1 \\
\hline Pengambilan uang secara paksa & 12 & 18,5 \\
\hline \multicolumn{3}{|l|}{ Pelaku bullying } \\
\hline Teman sebaya & 55 & 84,6 \\
\hline Kakak kelas & 20 & 30,8 \\
\hline Adik kelas & 11 & 16,9 \\
\hline \multicolumn{3}{|l|}{ Lokasi bullying } \\
\hline Kelas & 45 & 69,2 \\
\hline Lorong/koridor & 8 & 12,3 \\
\hline Lapangan bermain & 26 & 40 \\
\hline Kantin & 13 & 20 \\
\hline Kamar mandi & 3 & 4,6 \\
\hline Jalan menuju atau pulang sekolah & 8 & 12,3 \\
\hline \multicolumn{3}{|l|}{ Waktu terjadinya bullying } \\
\hline Sedang belajar & 20 & 30,8 \\
\hline Pergantian mata pelajaran & 8 & 12,3 \\
\hline Istirahat & 47 & 72,3 \\
\hline Pulang sekolah & 18 & 27,7 \\
\hline \multicolumn{3}{|l|}{ Dampak bullying } \\
\hline Malu & 12 & 18,5 \\
\hline Sedih & 27 & 41,5 \\
\hline Tidak senang & 17 & 26,2 \\
\hline Marah & 21 & 32,3 \\
\hline Ingin membalas & 16 & 24,6 \\
\hline Ketakutan & 5 & 7,7 \\
\hline Malas pergi ke sekolah & 5 & 7,7 \\
\hline Ingin pindah sekolah & 7 & 10,8 \\
\hline Biasa-biasa saja & 12 & 18,5 \\
\hline \multicolumn{3}{|l|}{ Pelaporan } \\
\hline Teman & 31 & 60,8 \\
\hline Kakak/adik & 13 & 25,5 \\
\hline Orang tua & 29 & 56,9 \\
\hline Guru & 9 & 17,6 \\
\hline
\end{tabular}


Tipe bullying fisik, pemalakan uang, dan pengambilan/perusakkan barang milik pribadi paling sering dialami korban berjenis kelamin laki-laki dibandingkan perempuan. Kebanyakan korban mengaku mendapat perlakuan negatif dari beberapa murid atau kelompok murid yang berbeda-beda. Tidak ada orang dewasa yang menjadi pelaku bullying di sekolah. Tujuh puluh satu persen korban berjenis kelamin laki-laki mengaku di-bully terutama oleh anak laki-laki, sedangkan 41,2\% korban berjenis kelamin perempuan mengaku di-bully oleh anak laki-laki dan perempuan. Hanya 16,1\% korban berjenis kelamin laki-laki yang mengaku pelaku bullying utama berjenis kelamin perempuan.

Didapatkan 51/65 (78,5\%) korban melaporkan bullying yang dialaminya kepada orang lain. Dari 51 korban bullying yang melapor, kebanyakan korban bercerita kepada teman, hanya 9/51 siswa yang bercerita kepada guru. Reaksi terhadap pelaporan tersebut beragam, sebagian besar orang yang mendapat laporan tersebut berusaha menghentikan perilaku tersebut, tetapi $25,5 \%$ lainnya bersikap diam saja atau tidak menganggap serius pelaporan tersebut. Pengakuan korban bullying yang dialaminya pernah disaksikan oleh guru (52/65). Berdasarkan pengakuan korban, sebagian besar $(46 / 52)$ guru yang melihat perilaku tersebut berusaha menghentikan dan hanya sebagian kecil (6/52) dari mereka yang tidak berbuat apa-apa.

Proporsi subyek berjenis kelamin perempuan dan laki-laki yang terlibat dalam perilaku bullying sama besar (89,7\% versus $89,2 \%)$. Kebanyakan subyek perempuan menjadi korban bullying, dan korban sekaligus pelaku. Dibandingkan murid laki-laki, murid perempuan lebih banyak menjadi korban bullying, sedangkan murid laki-laki lebih banyak menjadi pelaku dan korban sekaligus pelaku bullying dibandingkan murid perempuan. Secara umum, murid yang terlibat bullying berusia lebih tua ( $>9$ tahun). Subyek dengan status sosio-ekonomi rendah cenderung menjadi korban, sedangkan subyek dengan status sosioekonomi menengah dan tinggi cenderung menjadi korban sekaligus pelaku. Tidak ada pelaku murni yang berasal dari status sosio-ekonomi rendah.

\section{Hubungan antara pengetahuan dengan kesesuaian antara status bullying dan pengakuan menjadi korban/pelaku}

Tigapuluh dua persen subyek pernah mendengar istilah bullying dan 68\% di antaranya menjawab definisi bullying dengan tepat. Tidak semua korban mengaku/ menganggap perilaku yang dialaminya sebagai bullying. Dari 65 subyek yang menjadi korban, hanya $11 \%$ subyek yang mengaku sebagai korban. Proporsi kesesuaian antara status bullying dan pengakuan menjadi korban lebih tinggi pada kelompok subyek yang mengetahui definisi bullying dengan tepat dibandingkan subyek yang tidak pernah mendengar istilah bullying maupun salah menjawab $(47,1 \%$ versus $5,1 \%, P=0,00)$. Dari 38 subyek yang menjadi pelaku, hanya $13 \%$ subyek yang mengaku sebagai pelaku. Subyek dengan pengetahuan yang baik tentang definisi bullying memiliki proporsi kesesuaian antara status bullying dan pengakuan menjadi pelaku yang lebih tinggi dibandingkan subyek yang tidak pernah mendengar istilah bullying maupun salah menjawab, namun perbedaan ini tidak bermakna secara statistik ( $47,1 \%$ versus $27,1 \%, \mathrm{P}=0,119)$.

\section{Masalah emosi dan perilaku}

Penilaian skor total SDQ mengindikasikan 8/76 subyek memiliki masalah emosi dan perilaku, dan sebagian besar (7/8) berasal dari kelompok korban sekaligus pelaku. Tidak ada subyek dari kelompok pelaku maupun tidak terlibat dalam bullying yang memiliki masalah emosi dan perilaku berdasarkan penilaian skor total. Proporsi masalah emosi dan perilaku tidak berbeda bermakna antara anak yang terlibat dan tidak terlibat bullying $(\mathrm{P}=0,59)$.

Pada penilaian skor masing-masing ranah, proporsi masalah terbesar yang dijumpai adalah masalah conduct. Secara umum, masalah emosi dan perilaku terbanyak dijumpai pada kelompok korban sekaligus pelaku (19 masalah/35 subyek) dan paling sedikit pada subyek yang tidak terlibat bullying ( 2 masalah/8 subyek). Sebaran masalah emosi dan perilaku yang spesifik tertera pada Tabel 4.

Tidak terdapat hubungan antara keterlibatan dalam bullying dengan masalah emosi dan perilaku.

\section{Prestasi akademis}

Secara umum, prestasi akademis subyek yang terlibat dalam perilaku bullying hanya sedikit lebih rendah dibandingkan subyek yang tidak terlibat (Rerata nilai 71 (SB 8,4) versus 73,4 (SB 7,5); $\mathrm{P}=0,4)$. Kelompok korban memiliki prestasi akademis paling rendah dibandingkan kelompok lainnya. Tidak terdapat perbedaan rerata nilai prestasi akademis antara keempat kelompok tersebut $(\mathrm{P}=0,07)$. 
Soedjatmiko dkk: Gambaran bullying dan hubungannya dengan masalah emosi dan perilaku pada anak

Tabel 4. Sebaran masalah emosi dan perilaku menurut status bullying

\begin{tabular}{lcccc}
\hline Masalah emosi dan perilaku & \multicolumn{3}{c}{ Terlibat $(\mathrm{n}=68)$} & Tidak terlibat \\
\cline { 2 - 4 } & Korban $(\mathrm{n}=30)$ & $\begin{array}{c}\text { Korban sekaligus } \\
\text { pelaku }(\mathrm{n}=35)\end{array}$ & $\begin{array}{c}\text { Pelaku } \\
(\mathrm{n}=3)\end{array}$ & $\begin{array}{c}\mathrm{n}=8) \\
\text { Masalah emosi }\end{array}$ \\
Masalah conduct & 2 & 4 & 0 & 1 \\
Hubungan dengan teman sebaya & 1 & 11 & 1 & 1 \\
Hiperaktivitas & 1 & 1 & 0 & 0 \\
\hline
\end{tabular}

\section{Pembahasan}

Prevalensi bullying penelitian kami 89,5\% dengan proporsi terbesar adalah kelompok korban sekaligus pelaku (46,1\%). Angka ini lebih tinggi dibanding penelitian serupa di negara lain. Faktor-faktor yang menyebabkan perbedaan prevalensi bullying antar penelitian, antara lain adanya perbedaan metodologi penelitian (desain penelitian, batasan operasional, metode, instrumen, klasifikasi status, dan lama pengukuran), usia, dan lokasi penelitian (karakteristik sosiodemografi, budaya). ${ }^{16,17}$

Perbedaan mendasar kuesioner bullying yang digunakan penelitian kami dengan kuesioner yang digunakan oleh peneliti lain adalah pada penggunaan kata bullying. Pertanyaan-pertanyaan dalam kuesioner yang digunakan pada sebagian besar penelitian secara lugas menggunakan istilah bullying. Hal yang sama sulit diterapkan pada penelitian kami sebab bullying bukanlah istilah yang awam bagi kebanyakan siswa di Indonesia, apalagi siswa SD. Terbukti hanya 17/76 $(22,4 \%)$ subyek yang dapat menjawab pertanyaan mengenai definisi bullying dengan tepat.

Tipe bullying tersering yang kami dapatkan adalah fisik, diikuti verbal, psikologis, dan emosional. Menurut Olweus, ${ }^{18}$ bentuk bullying tersering di sekolah ialah ejekan, diikuti pemukulan, ancaman, dan penyebaran gosip. Penelitian Kshirsagar $\mathrm{dkk}^{19}$ memperlihatkan tipe bullying tersering pada anak SD di India ialah verbal (ejekan, nama panggilan), diikuti psikologis, dan emosional (penyebaran gosip, isolasi sosial). Hasil penelitian kami sesungguhnya tidak berbeda dengan penelitian Olweus maupun Kshirsagar karena proporsi bullying tipe fisik dan verbal tidak berbeda jauh $(93,8 \%$ versus $90,8 \%)$. Prevalensi cyberbullying adalah 26,2\%, lebih besar dari penelitian Williams dkk. ${ }^{20}$ Perbedaan tersebut timbul karena penelitian Williams tidak memperhitungkan bullying yang dilakukan via telepon selular.
Penelitian kami dan penelitian Fekkes $\mathrm{dkk}^{21}$ memiliki kesamaan, yaitu melihat kecenderungan bahwa anak laki-laki melakukan bullying terhadap anak laki-laki dan perempuan, sedangkan anak perempuan melakukan bullying terhadap anak perempuan lain. Kebanyakan pelaku melakukan bullying terhadap anak seusianya, hanya 30\% korban yang mengaku pelaku bullying berusia lebih tua, dan kurang lebih $10 \%$ korban mengaku pelaku berusia lebih muda. ${ }^{22}$ Pelaku bullying pada penelitian kami sebagian besar adalah teman sebaya. Laporan tersebut sama dengan studi yang dilakukan di Belanda ${ }^{21}$ dan Jepang, ${ }^{23}$ tetapi berbeda dengan penelitian Olweus ${ }^{18}$ di Norwegia, saat pelaku umumnya berusia lebih tua.

Bullying di sekolah paling sering terjadi di lapangan bermain. ${ }^{21,24}$ Temuan tersebut berbeda dengan penelitian kami maupun penelitian di Jepang yang mendapati ruang kelas sebagai lokasi tersering terjadinya bullying. ${ }^{23}$ Interaksi antar-murid paling banyak terjadi di lapangan bermain dan kelas, sehingga bullying paling sering dialami korban di kedua lokasi tersebut. ${ }^{21}$ Bullying dapat terjadi dimana saja, terutama di lokasi yang minim pengawasan oleh orang dewasa. ${ }^{1,14,22}$ Pada penelitian kami, kejadian bullying yang tinggi di dalam kelas mungkin disebabkan kurangnya pengawasan guru, akibat rasio guru dan murid yang tinggi, yaitu 1:20-37. Sebagai perbandingan, rasio guru-murid SD di Jakarta Pusat adalah 1:20. ${ }^{25}$ Rasio guru-murid SD yang ideal adalah 1:6-10. ${ }^{26}$

Korban bullying melaporkan peristiwa yang dialaminya kepada orang lain $(78,5 \%)$, tetapi sebagian besar korban menceritakannya kepada teman dan anggota keluarga (orangtua, saudara kandung), bukan kepada guru ataupun staf sekolah lainnya. Glew $\mathrm{dkk}^{24}$ mendapatkan angka pelaporan yang lebih rendah (50\%). Sama halnya dengan penelitian kami, Glew juga mendapati sebagian besar korban lebih memilih bercerita kepada anggota keluarga di rumah. Penelitian Fekkes dkk ${ }^{21}$ juga memperlihatkan lebih banyak 
korban bullying yang melapor kepada orangtuanya dibanding guru sekolah $(73,8 \%$ versus $58,5 \%)$. Kami menekankan pentingnya komunikasi guru dan orangtua untuk mendeteksi bullying pada anak.

Keengganan murid untuk melaporkan bullying yang dialaminya kepada guru mungkin disebabkan rasa percaya murid yang kurang terhadap guru. Pada tahun 2007, $\mathrm{Amy}^{8}$ melakukan wawancara terhadap 9 guru SD tentang persepsi mereka terhadap bullying. Mayoritas guru tersebut menganggap bullying merupakan hal yang lumrah terjadi dalam interaksi antar anak saat bermain dan bagian dari proses pendewasaan seorang anak. Mereka tidak menganggap bullying sebagai perilaku yang bertentangan dengan norma sosial. Beberapa di antaranya, bahkan melakukan bullying verbal, fisik, maupun psikologis terhadap muridnya sebagai upaya penegakan disiplin sekolah. Ada pula guru yang mempraktikkan bullying sebagai sanksi terhadap pelaku bullying (mengatasi bullying dengan bullying), bahkan memerintahkan siswanya melakukan bullying terhadap siswa lain. ${ }^{8}$ Penelitian yang dilakukan oleh Yayasan SEJIWA $^{27}$ memperlihatkan tidak semua guru tanggap dan bereaksi positif terhadap perilaku kekerasan yang terjadi di sekolah. Persepsi, sikap, dan tindakan guru yang salah terhadap perilaku ini mengakibatkan rendahnya rasa percaya murid terhadap institusi pendidikan dan menyuburkan perilaku bullying di sekolah. Padahal, kemampuan guru untuk menumbuhkan rasa percaya murid dan meniadakan jarak antara guru dan murid merupakan modal dasar untuk memerangi bullying di lingkungan sekolah.

Masalah emosi dan perilaku lebih banyak dijumpai pada anak yang terlibat bullying dibandingkan mereka yang tidak terlibat. ${ }^{6}$ Kami tidak menemukan masalah emosi dan perilaku pada anak yang tidak terlibat bullying berdasarkan penilaian skor total. Hasil penelitian kami sejalan dengan penelitian $\mathrm{Gini}^{28}$ yang juga menggunakan instrumen SDQ, tetapi dengan metode teacher-rated. Berdasarkan penilaian skor total, Gini ${ }^{28}$ menemukan proporsi masalah emosi dan perilaku pada anak yang tidak terlibat dalam bullying $(13,5 \%)$ lebih sedikit dibanding anak yang terlibat, baik sebagai korban $(40 \%)$, pelaku $(14,3 \%)$, dan korban sekaligus pelaku $(27,1 \%)$.

Di antara subyek yang terlibat dalam bullying, kelompok korban sekaligus pelaku memiliki risiko paling tinggi timbulnya perilaku psikopatologis. ${ }^{14}$ Penelitian kami dan beberapa penelitian lain (Nansel $\mathrm{dkk}^{6}$, Kim $\mathrm{dkk}^{29}$ ) memperlihatkan proporsi masalah emosi dan perilaku paling tinggi ada pada kelompok korban sekaligus pelaku.

Selain berdampak terhadap kesehatan, bullying juga berdampak pada prestasi akademis siswa. Penelitian kami sejalan dengan penelitian Glew $\mathrm{dkk}^{24}$ yang memperlihatkan pencapaian prestasi akademis pada subyek yang terlibat bullying lebih rendah dibandingkan subyek yang tidak terlibat. Korban dan korban sekaligus pelaku memiliki prestasi akademis yang paling rendah. Berbeda dengan penelitian Glew dkk, pada penelitian kami pelaku memiliki prestasi akademis yang lebih tinggi, bahkan apabila dibandingkan dengan mereka yang tidak terlibat. Hasil tersebut dapat memunculkan hipotesis baru, yaitu siswa yang berprestasi cenderung menjadi pelaku bullying karena dianggap sebagai faktor "kekuatan".

Kelemahan penelitian kami adalah penilaian validitas kuesioner bullying yang digunakan kurang lengkap. Hubungan kausalitas antara bullying dan masalah emosi serta perilaku, bullying dan prestasi akademis, tidak dapat ditetapkan secara pasti mengingat sifat alamiah desain penelitian potong lintang dan jumlah subyek yang sedikit. Demikian pula dengan pengukuran prestasi akademis yang hanya berdasarkan nilai ujian tengah semester tidak dapat menggambarkan prestasi akademis siswa secara keseluruhan. Hasil penelitian kami mungkin tidak dapat mewakili seluruh anak SD di Jakarta Pusat mengingat jumlah subyeknya yang kecil. Perlu dilakukan penelitian lebih lanjut untuk mencari prevalensi bullying pada anak SD dengan metode lain dan melibatkan lebih banyak subyek dari berbagai tingkatan kelas. Penelitian dengan desain kohort perlu dilakukan untuk menilai hubungan antara bullying dengan masalah emosi dan perilaku dan prestasi akademis siswa.

\section{Daftar pustaka}

1. Glew G, Rivara F, Feudtner C. Bullying: children hurting children. Pediatr Rev 2000;21:183-9.

2. Dawkins J. Bullying in school: doctor's responsibility. BMJ 1995;310:274-5.

3. Kim YS, Koh YJ, Leventhal BL. Prevalence of school bullying in Korean middle school students. Arch Pediatr Adolesc Med 2004;158:737-41.

4. Wolke D, Woods S, Stanford K, Schultz H. Bullying and victimization of primary school children in England and Germany: prevalence and school factors. Br J Psychol 
2001;92:673-96.

5. Kumpulainen K, Räsänen E, Hentonen I. Bullying and psychiatric symptoms among elementary school-age children. Child Abuse Negl 1998;22:705-17.

6. Nansel TR, Overpeck M, Pilla RS, Ruan WJ, Morton BS, Scheidt P. Bullying behaviour among US youth. JAMA 2001;285:2094-100.

7. Baldry AC. Bullying among Italian middle school students: combining methods to understand aggressive behaviours and victimization. Sch Psychol Int 1998;19:361-74.

8. Huneck A. Bullying: a cross-cultural comparison of one American and one Indonesian elementary school (disertasi). Cincinnati: Union Institute \& University, 2007.h.88-94.

9. Komisi Perlindungan Anak. Bullying bikin anak depresi dan bunuh diri. [diakses pada: 20 Agustus 2007]; Diunduh dari: http://www.kpai.go.idmn_access.phpto=2artikel.

10. Weir E. The health impact of bullying. Can Med Assoc J 2001;165:1249.

11. Neto AAL. Bullying-aggressive behavior among students. J Pediatr 2005;81:(S) 164-72.

12. Yayasan Pemantau Hak Anak. "Bullying" bentuk kebobrokan mental. [diakses pada: 20 Agustus 2007]; Diunduh dari: http://www.ypha.or.id/search.php?dosearch= yeserstory= bullying.

13. Lyznicki JM, Mccaffree MA, Robinowitz CB. Childhood bullying: implications for physicians. Am Fam Physician 2004;70:1723-30.

14. Vanderbilt D. Bullying. Dalam: Steven Parker, Barry Zuckerman, Marilyn Augustyn, penyunting. Developmental and Behavioral Pediatrics. Edisi ke-2. Philadelphia: Lippincott; 2005.h.141-5.

15. Solberg EM, Olweus D. Prevalence estimation of school bullying with the Olweus bully/victim questionnaire. Aggress Behav 2003;29:239-68.

16. Fekkes M, Pipers FIM, Vanhorick PV. Bullying behavior and associations with psychosomatic complaints and depression in victims. J Pediatr 2004;144:17-22.

17. Analitis F, Velderman MK, Sieberer UR, dkk. Being bullied: associated factors in children and adolescent 8 to 18 years old in 11 European countries. Pediatrics 2009; 123:569-77.

18. Olweus D. Bullying at school:basic fact and effect of a school based intervention program. J Child Psychol Psychiatry 1994;35:171-90.

19. Kshirsagar VY, Agarwal R, Bavdekar SB. Bullying in school: prevalence and short-term impact. Indian Pediatrics 2007;44:28.

20. Williams KR, Guerra NG. Prevalence and predictors of internet bullying. J Adolesc Health 2007;41:14-21.

21. Fekkes M, Pijpers FIM, Verloove-Vanhorick SP. Bullying: who does what, when and where? Health Educ Sampson R. Problem oriented guides for police series no.12: bullying in school. Washington: US Department of Justice; 2002.

22. Taki M. Japanese school bullying: ijime. [diakses pada: 8 November 2011]; Diunduh dari: http://www.nier.go.jp/ a000110/Toronto.pdf.

23. Glew G, Fan MY, Katon W, Rivara FP, Kernic MA. Bullying, psychosocial adjustment and academic performance in elementary school. Arch Pediatr Adolesc Med 2005;159:1026-31.

24. Badan Pusat Statistik Kota Administrasi Jakarta Pusat. Sosial. Dalam: Badan Pusat Statistik Kota Administrasi Jakarta Pusat, penyunting. Jakarta Pusat dalam angka. Jakarta: Badan Pusat Statistik Kota Administrasi Jakarta Pusat; 2010.h.89-102.

25. Institut Teknologi Bandung. Presentasi terbuka: pendidikan alternatif. [diakses pada 1 Desember 2011]. Diunduh dari: http://www.itb.ac.id/news/2465.xhtml.

26. Yayasan Semai Jiwa Amini. Bullying: mengatasi kekerasan di sekolah dan lingkungan sekitar anak. Nusantara A, penyunting. Jakarta: Grasindo;2008.

27. Gini G. Association between bullying behavior, psychosomatic complaints, emotional and behavioural problems. J Pediatr Child Health 2008;44:492-7.

28. Kim YS, Leventhal BL, Koh YJ, Hubbard A, Boyce WT. School bullying and youth violence. Arch Gen Psychiatry 2006;63:1035-41. 